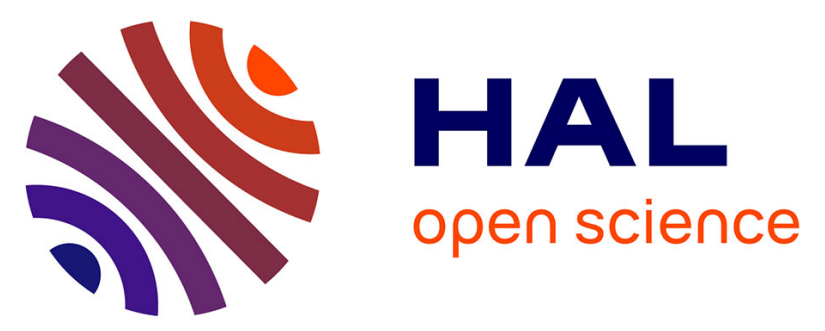

\title{
Links between topography, wind, deflation, lakes and dust: The case of the Bodélé Depression, Chad
}

R. Washington, M.C. Todd, G. Lizcano, I. Tegen, Cyrille Flamant, I. Koren, P. Ginoux, S. Engelstaedter, C.S. Bristow, C.S. Zender, et al.

\section{- To cite this version:}

R. Washington, M.C. Todd, G. Lizcano, I. Tegen, Cyrille Flamant, et al.. Links between topography, wind, deflation, lakes and dust: The case of the Bodélé Depression, Chad. Geophysical Research Letters, 2006, 33 (9), pp.L09401. 10.1029/2006GL025827 · hal-00069281

\section{HAL Id: hal-00069281 https://hal.science/hal-00069281}

Submitted on 5 Dec 2017

HAL is a multi-disciplinary open access archive for the deposit and dissemination of scientific research documents, whether they are published or not. The documents may come from teaching and research institutions in France or abroad, or from public or private research centers.
L'archive ouverte pluridisciplinaire HAL, est destinée au dépôt et à la diffusion de documents scientifiques de niveau recherche, publiés ou non, émanant des établissements d'enseignement et de recherche français ou étrangers, des laboratoires publics ou privés. 


\title{
Links between topography, wind, deflation, lakes and dust: The case of the Bodélé Depression, Chad
}

\author{
R. Washington, ${ }^{1}$ M. C. Todd, ${ }^{2}$ G. Lizcano, ${ }^{1}$ I. Tegen, ${ }^{3}$ C. Flamant, ${ }^{4}$ I. Koren, ${ }^{5}$ \\ P. Ginoux, ${ }^{6}$ S. Engelstaedter, ${ }^{1}$ C. S. Bristow, ${ }^{7}$ C. S. Zender, ${ }^{8}$ A. S. Goudie, ${ }^{1}$ A. Warren, ${ }^{2}$ \\ and J. M. Prospero 9 \\ Received 25 January 2006; revised 13 March 2006; accepted 30 March 2006; published 4 May 2006.
}

[1] The Bodéle Depression, Chad is the planet's largest single source of dust. Deflation from the Bodélé could be seen as a simple coincidence of two key prerequisites: strong surface winds and a large source of suitable sediment. But here we hypothesise that long term links between topography, winds, deflation and dust ensure the maintenance of the dust source such that these two apparently coincidental key ingredients are connected by land-atmosphere processes with topography acting as the overall controlling agent. We use a variety of observational and numerical techniques, including a regional climate model, to show that: 1) contemporary deflation from the Bodélé is delineated by topography and a surface wind stress maximum; 2) the Tibesti and Ennedi mountains play a key role in the generation of the erosive winds in the form of the Bodélé Low Level Jet (LLJ); 3) enhanced deflation from a stronger Bodélé LLJ during drier phases, for example, the Last Glacial Maximum, was probably sufficient to create the shallow lake in which diatoms lived during wetter phases, such as the Holocene pluvial. Winds may therefore have helped to create the depression in which erodible diatom material accumulated. Instead of a simple coincidence of nature, dust from the world's largest source may result from the operation of long term processes on paleo timescales which have led to ideal conditions for dust generation in the world's largest dust source. Similar processes plausibly operate in other dust hotspots in topographic depressions. Citation: Washington, R., et al. (2006), Links between topography, wind, deflation, lakes and dust: The case of the Bodélé Depression, Chad, Geophys. Res. Lett., 33, L09401, doi:10.1029/2006GL025827.

${ }^{1}$ Climate Research Lab, Center for the Environment, Oxford University, Oxford, UK.

${ }^{2}$ Department of Geography, University College London, 26 Bedford Way, London, UK.

${ }^{3}$ Institute for Tropospheric Research, Leipzig, Germany.

${ }^{4}$ IPSL/Service d'Aéronomie, Université Pierre et Marie Curie, Paris, France.

${ }^{5}$ Department of Environmental Sciences, Weizmann Institute, Rehovot, Israel.

${ }^{6}$ National Oceanic and Atmospheric Administration, Geophysical Fluid Dynamics Laboratory, Princeton, New Jersey, USA.

${ }^{7}$ School of Earth Sciences, Birkbeck College, University of London, London, UK.

${ }^{8}$ Department of Earth System Science, University of California, Irvine, California, USA.

${ }^{9}$ University of Miami, Rosenstiel School of Marine and Atmospheric Science, Miami, Florida, USA.

Copyright 2006 by the American Geophysical Union. 0094-8276/06/2006GL025827

\section{Introduction}

[2] Dust is known to play an important role in climate and the environment [e.g., Mahowald and Kiehl, 2003]. The realistic simulation of past and future climates requires the inclusion of dust-related processes. Dust source regions cannot easily be specified in such simulations, sources need to be determined from first principles, which, in turn, requires that the complex processes leading to dustgeneration are understood and included in models.

[3] A variety of data sources point to the Bodélé Depression, Chad, as the world's premier source [Washington et al., 2003]. Two factors account for this. First the Bodélé is a very large source of erodible sediment comprising diatomite associated with Mega-Lake Chad [Gasse, 2002], which, in a vegetation free hyper arid location, ensures extreme erodibility. Secondly, the Bodélé Low Level Jet (LLJ) [Washington and Todd, 2005] is focused onto the erodible sediments.

[4] Dust from the Bodélé may be seen as a simple coincidence of two key requirements for deflation: strong surface winds and erodible sediment. But here we argue that long-term links exist between topography, wind, deflation and dust and that topography acts as the controlling agent ensuring the long term maintenance of this source. The spatial co-location of strong winds and dust is not simply fortuitous but results from a set of processes. Specifically we argue that: 1) contemporary deflation from the Bodélé is delineated by topography such that wind stress, the maximum in dust output and the topographic depression are colocated, 2) the topography of the Tibesti and Ennedi Mountains plays a key role in the generation of the Bodélé LLJ, 3) enhanced deflation from a stronger Bodélé LLJ during drier phases, such as the Last Glacial Maximum (LGM) was probably sufficient to create or enhance a shallow lake populated by diatoms during wetter phases, such as the Holocene pluvial. Wind conditions which deflate the erodible sediment now may have created the depression necessary for generating the erodible diatomite in the past. Instead of a simple coincidence of nature, we hypothesise that dust from the world's largest source results from a system of processes operating over paleo timescales.

\section{Topography and Deflation}

[5] There is a well established connection between topographic depressions and preferred source regions of dust [Ginoux et al., 2001; Prospero et al., 2002; Washington et al., 2003; Tegen et al., 2002; Zender et al., 2003]. Ginoux et al. [2001], for example, specify that the most probable dust sources relate to the degree of topographic depression, thereby improving dust simulation in comparison with 


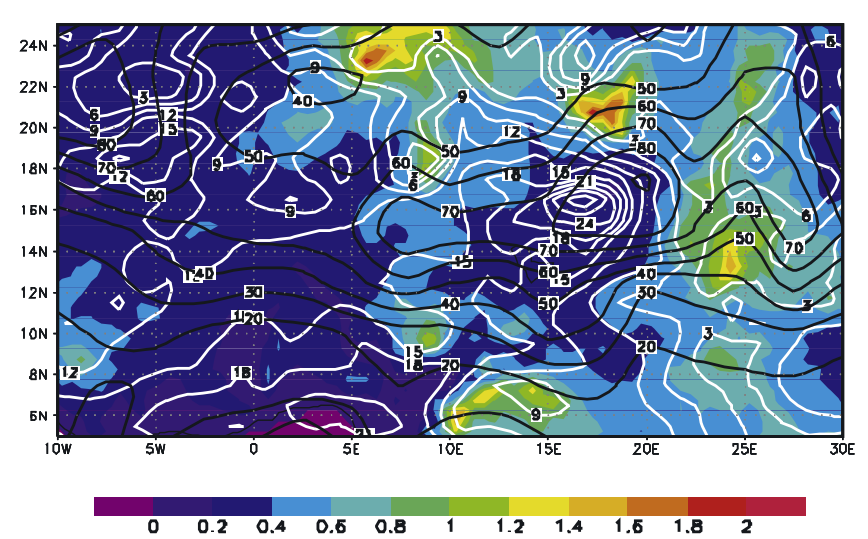

Figure 1. Topography in km (shading), TOMS AI (x10) January to March mean 1980-92 (white contours) and potential sand flux (black contours).

satellite derived estimates. Dust generation, a topographic depression and the maximum in potential sand flux are colocated in the Bodélé (Figure 1).

\section{Topography and the Bodélé Low Level Jet}

[6] The Bodélé LLJ is a key feature of the mean low level atmospheric circulation over the Bodélé [Washington and Todd, 2005] which coincides with the north-easterlies' exit gap between the Tibesti and Ennedi mountains. Vertical velocity fields also point to the influence of topography. Pronounced downslope flow, a unique feature of the climatology of the Bodélé region, develops in the lee of the Tibesti. The subsidence core occurs at c1.5 km overlying the depression at $18^{\circ} \mathrm{N}$ (Figure 2) and is modulated in phase with extremes in monthly dust values as sampled from a TOMS optical thickness index of the Bodélé (Figure 3) [for details see Washington and Todd, 2005]. Anomalously strong downslope flow and enhanced wind erosivity in the depression are statistically linked. Gap flows such as the Bodélé Low Level

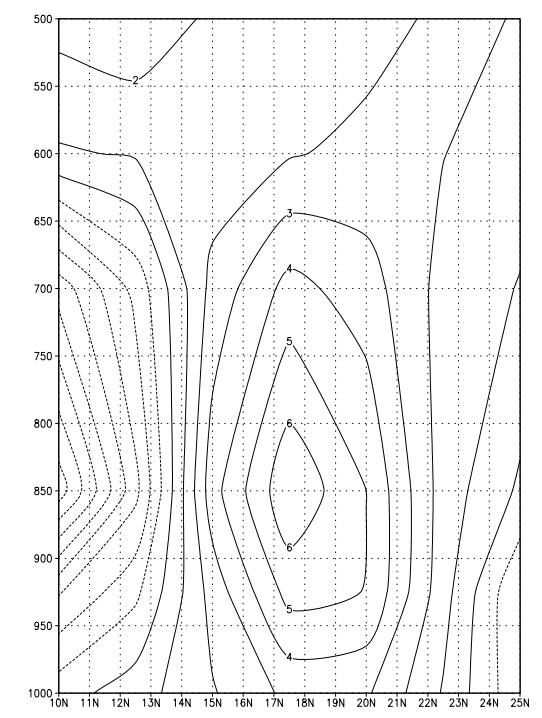

Figure 2. Longitude-height (pressure in $\mathrm{hPa}$ ) section along $18^{\circ} \mathrm{E}$ between $10^{\circ} \mathrm{N}-25^{\circ} \mathrm{N}$ of mean (1979-1992) January to April NCEP vertical velocity $\left(\mathrm{Pa}_{\mathrm{s}}{ }^{-1 * 100)}\right.$. Positive values indicate subsidence.

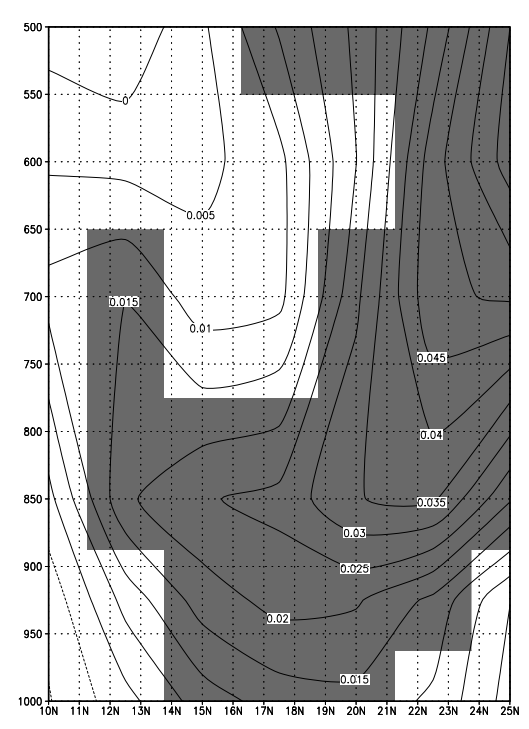

Figure 3. Longitude-height (pressure in $\mathrm{hPa}$ ) section along $18^{\circ} \mathrm{E}$ between $10^{\circ} \mathrm{N}-25^{\circ} \mathrm{N}$ of vertical velocity $\left(\mathrm{Pa} . \mathrm{s}^{-1} * 100\right)$ composite difference anomalies for a sample of 8 high minus 8 low dust months during January-April 1979-92. Contours $0.05 \mathrm{~Pa}^{-1}{ }^{-1}$; shading shows significant differences at 0.05 levels.

Jet are well known features of topographically constrained low level circulation [Flamant et al., 2002].

[7] To quantify the role of topography in windspeeds, we have run experiments with the Penn State University/NCAR model MM5 [Grell et al., 1994] configured with a two-way nesting (mother domain resolution $=81 \mathrm{~km}$ covering $4.4^{\circ} \mathrm{N}-34.2^{\circ} \mathrm{N}, 4.0^{\circ} \mathrm{E}-36.0^{\circ} \mathrm{E}$, nest resolution $=27 \mathrm{~km}$ over $9^{\circ} \mathrm{N}-24^{\circ} \mathrm{N}, 9^{\circ} \mathrm{E}-24^{\circ} \mathrm{E}$, centred on the Bodélé). Six hourly NCEP boundary conditions were used and the Noah Land Surface Model and the MRF boundary layer schemes specified. In the TOPO experiment, topography was defined at the nested model resolution. In the NOTOPO experiment, topography was reduced to $300 \mathrm{~m}$ above sea level. The runs covered the BoDEx period of 25 February to 12 March 2005 [Washington et al., 2006], so model winds could be compared with the only existing observations.

[8] The Bodélé LLJ is clearly evident in wind speeds averaged over the BoDEx period in the TOPO experiment
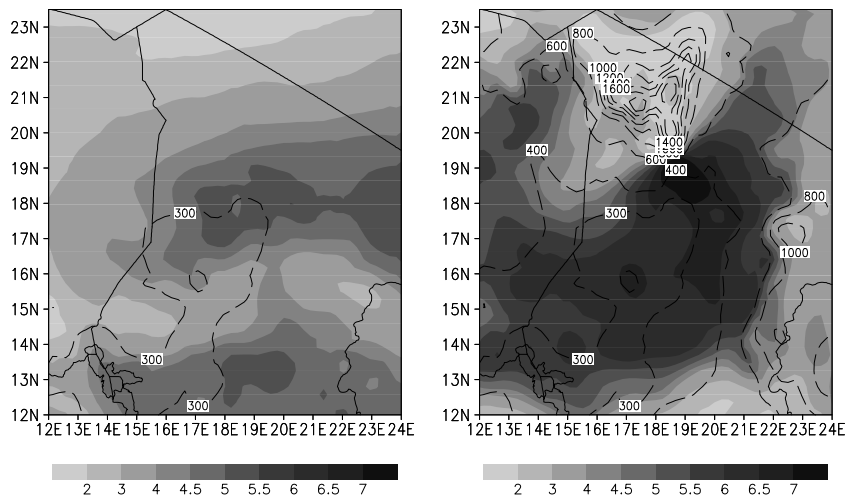

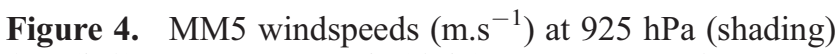
for (left) NOTOPO and (right) TOPO experiment 28 February to 12 March 2005. Contours are topography in meters. 

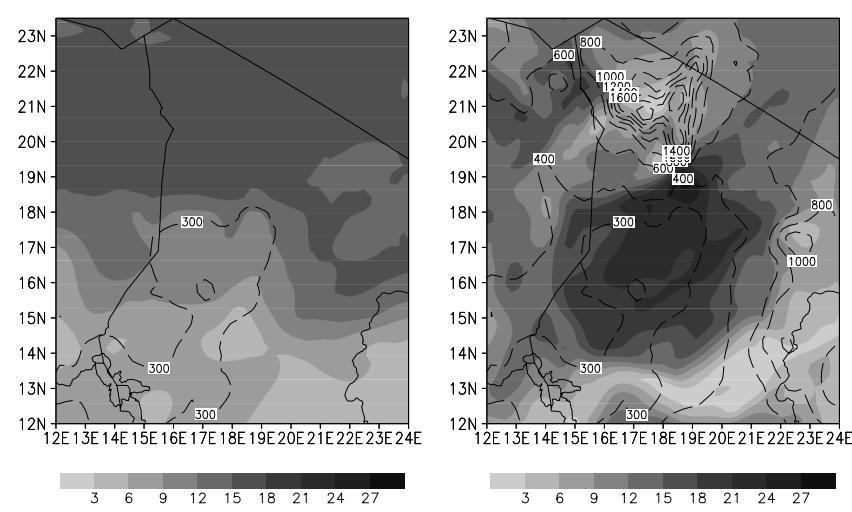

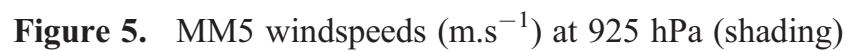
for the (left) NOTOPO and (right) TOPO experiment for 10 March 2005. Contours are topography in meters.

where a jet maximum of $-9 \mathrm{~m} . \mathrm{s}^{-1}$ overlies the northern part of the depression. This is in good agreement with observations from BoDEx [Washington et al., 2006]. In the NOTOPO experiment, the jet core is weaker and much reduced in spatial extent (Figure 4).

[9] A strong deflation event took place during BoDEx on 10 March 2005. The windspeed differences between the TOPO and NOTOPO experiments are much larger for this day (Figure 5) compared with the differences averaged over the BoDEx period. In the TOPO experiment winds peak at $>20 \mathrm{~m} . \mathrm{s}^{-1}$ but are some $30 \%$ slower in the NOTOP experiment. The large scale topography of the Tibesti and Ennedi therefore play an important role in increasing the magnitude of the jet over the Bodélé and increasing the frequency with which thresholds for deflation are reached.

\section{Deflation and Drier, Windier Times}

[10] Contemporary deflation from the Bodélé has been calculated between 640 and $780 \mathrm{Tg}^{\mathrm{yr}} \mathrm{yr}^{-1}$ from simulations with GOCART [Ginoux et al., 2001; Giles, 2005]. Using an estimated area of $200,000 \mathrm{~km}^{2}$ and an average density of the diatomite material of $0.8 \mathrm{~g} . \mathrm{cm}^{3}$ (established from field samples), this equates to a lowering of the depression of between 0.26 and $0.31 \mathrm{~cm} . y r^{-1}$, comparing well with rates estimated elsewhere (Table 1) and observed flux estimates from BoDEx (180Tg. $\mathrm{yr}^{-1}$ yielding $0.3 \mathrm{~cm} . \mathrm{yr}^{-1}$ over the diatomite surface (M. Todd et al., Optical properties of mineral dust from the Bodélé Depression, Northern Chad during BoDEx, submitted to J. Geophys. Res., 2006). Dust flux estimates from Tegen (personal communication, 2005) and Zender [2003] are lower at 120 to 200 and 215 to 265 Tg. $\mathrm{yr}^{-1}$ respectively, although still within broad agreement. Rates of deflation are conservative since dust models simulate fine dust $(<6 \mu \mathrm{m})$ removal only. Assuming a constant deflation based on all these values, a $20 \mathrm{~m}$
Table 2. Spatial and Vertical Resolutions and Sea Surface Temperature Forcing Mode of 12 Climate Models Used to Assess the Changes in the Bodélé Low Level Jet Windspeed at the LGM

\begin{tabular}{lccccc}
\hline & Latitude & Longitude & Vertical & SSTs & Percent u Increase \\
\hline CCM1 & 4.5 & 7.5 & 12 & $\mathrm{C}$ & 18 \\
GFDL & 2.25 & 3.75 & 20 & $\mathrm{C}$ & 44 \\
GEN2 & 3.75 & 3.75 & 18 & $\mathrm{P}$ & 60 \\
GEN2 & 3.75 & 3.75 & 18 & $\mathrm{C}$ & 39 \\
ECHAM3 & 2.8 & 2.8 & 19 & $\mathrm{P}$ & 37 \\
UKMO & 2.5 & 3.75 & 19 & $\mathrm{C}$ & 16 \\
MRI2 & 4 & 5 & 15 & $\mathrm{C}$ & 61 \\
UGAMP & 2.8 & 2.8 & 19 & $\mathrm{C}$ & 16 \\
BMRC2 & 3.2 & 5.6 & 9 & $\mathrm{P}$ & 85 \\
CCSR1 & 5.6 & 5.6 & 20 & $\mathrm{P}$ & 24 \\
LMCELMD4 & 7.5 & 7.5 & 11 & $\mathrm{P}$ & 64 \\
LMCELMD5 & 3.6 & 5.6 & 11 & $\mathrm{P}$ & 5
\end{tabular}

${ }^{\mathrm{a}} \mathrm{P}=$ Prescribed SSTs, $\mathrm{C}=$ computed SSTs.

depression would take between approximately between 3000 and 8000 years to create.

[11] It is widely accepted that the atmosphere was dustier in the LGM, and this is hypothesized to be related to stronger winds [Kohfeld and Harrison, 2001]. Intense wind erosion produced mega-yardangs on the southeastern flanks of the Tibesti [Grove, 1960; Mainguet, 1970]. The yardangs conform closely to the direction of flow of the LLJ around the mountain today, strongly suggesting an active LLJ in the Pleistocene.

[12] In the Bodélé, yardangs aligned with the northeasterly wind have been carved from laminated diatomite eroding up to 4 metres of diatomite since the lake dried out. The lake bed may only have dried out within the past 1000 years [Servant and Servant, 1970; Gasse, 2000]. Rates of deflation within the Bodélé can also be derived from a small mesa sampled during BoDEx and subjected to OSL dating (sample number CH62). The sample has an age of $2.4 \pm 0.1 \mathrm{ka}$ and stands $4 \mathrm{~m}$ above the surrounding surface, yielding a deflation rate of $0.16 \mathrm{~cm} /$ year. Taken together the modelled, observed and proxy rates of deflation are in reasonable agreement.

[13] We have used 12 model simulations of the LGM to quantify a plausible increase in the Bodélé LLJ relative to the present. For inclusion in the assessment, each model was required in a contemporary run to show an increase in surface wind speed over the Bodélé (16 to $18^{\circ} \mathrm{N}$ compared with 13 to $15^{\circ} \mathrm{N}$ ) of at least $20 \%$ along or near $18^{\circ} \mathrm{E}$. All the simulations show an increase of the Bodélé LLJ at the LGM, providing an average increase of $30 \%$ on the control (modern) simulations (Table 2). Assuming the surface conditions were similar to present and a deep layer of erodible material, deflation could have created a $20 \mathrm{~m}$ depression in a shorter space of time in the LGM compared with now. Given that the Tibesti mountains have been in place for at least several million years [e.g., Gourgaud and Vincent, 2004], it is plausible that the Bodélé LLJ has had the opportunity to deflate a sizeable depression although

Table 1. Landform Based Deflation Estimates

\begin{tabular}{llll}
\hline \multicolumn{1}{c}{ Place } & \multicolumn{1}{c}{ Feature } & Rate of Deflation & Reference \\
\hline Saharan lakes & Yardangs & $0.4-4.0 \mathrm{~mm} / \mathrm{yr}$ & Cooke et al. [1993] \\
Kharga Oasis Egypt & Yardangs & $1 \mathrm{~mm} / \mathrm{yr}$ & Goudie et al. [1999] \\
Algeria & Sebka Mellala & $0.41 \mathrm{~mm} / \mathrm{yr}$ & Boye et al. $[1978]$ \\
Central Asia & Lop Nor yardangs & $20 \mathrm{~mm} / \mathrm{yr}$ & McCauley et al. [1977] \\
Mali & Araouane Basin & $0.092 \mathrm{~mm} / \mathrm{yr}$ & Riser $[1985]$ \\
Algeria & Biskra alluvium & $0.5 \mathrm{~mm}-2.0 \mathrm{~mm} / \mathrm{yr}$ & Williams [1970] \\
\hline
\end{tabular}


limits on the depth of deflation will be imposed by the depth of the water table, frequency of flooding [see Gasse, 2000] and the thickness of readily entrained sediment.

\section{Summary of the Linked Processes}

[14] The Bodélé Depression is known to be a globally important source of mineral aerosols. Its prominence in the Sahara arises from the surface erodibility and wind erosivity. We hypothesise that the spatial links between these components may not be coincidental. Deflation occurs preferentially from depressions (e.g., Figure 1). Numerical modelling shows that topographic channelling between the Tibesti and the Ennedi Massifenhances the LLJ which increases the frequency of erosive surface winds. We calculate that a $20 \mathrm{~m}$ depression would take between 3000 and 8000 years to form (assuming constant erosivity of wind and erodibility of material with depth). Model simulations of the LGM show an even stronger Bodélé LLJ and the likelihood of more rapid deflation then. Erosional features downwind of the Tibesti support this contention. The Holocene wet phase saw the shallow depression filled by Mega Lake Chad and populated with diatoms, which created the sediments that are now being deflated as dust. Taken over paleo timescales and probably involving a number of wet and dry phases, a combination of atmospheric, hydrological and geomorphological processes is responsible for maintaining and perhaps intensifying the greatest dust source on earth. It is likely that the Bodélé is an extreme example of a widespread phenomenon which sees the confluence of topographic and environmental factors to explain key dust source although the process itself may differ only in scale (time and space) from that suggested for ephemeral lakes on interannual time scales [Mahowald et al., 2003]. Freshwater diatoms in sediment traps distant from source [Romero et al., 2003] and off the main Bodélé transport pathway [Washington et al., 2006], suggests that the process outlined here for the Bodélé may occur elsewhere in the Sahara while the occurrence of global dust hotspots in topographic depressions suggests an even wider operation of these land surface-atmosphere interactions.

[15] Acknowledgments. The field work in the Bodele (BoDEx 2005) which gave rise to this paper was supported by the Gilchrist Educational Trust with the Gilchrist Fieldwork Award, administered by the Royal Geographical Society (with IBG).

\section{References}

Boyé, M., F. Marmier, C. Nesson, and G. Trécolle (1978), Les depôts de la Sebkha Mellala, Rev. Géomorphol. Dyn., 27, 49-62.

Cooke, R., A. Warren, A. Goudie (1993), Desert Geomorphology, Taylor and Francis, Philadelphia, Pa.

Flamant, C., P. Drobinski, L. Nance, R. Banta, L. Darby, J. Dusek, M. Hardesty, J. Pelon, and E. Richard (2002), Gap flow in an Alpine valley during a shallow south föhn event: Observations, numerical simulations and hydraulic analogue, Q. J. R. Meteorol. Soc., 128, 1173-1210.

Gasse, F. (2000), Hydrological changes in the African tropics since the Last Glacial Maximum, Quat. Sci. Rev., 19, 189-211.

Gasse, F. (2002), Diatom inferred salinity and carbonate oxygen isotopes in Holocene waterbodies of the western Sahara and Sahel (Africa), Quat. Sci. Rev., 21, 737-767.

Giles, J. (2005), The dustiest place on earth, Nature, 434, 816-819.

Ginoux, P., M. Chin, I. Tegen, J. M. Prospero, B. Holben, O. Dubovik, and S. Lin (2001), Sources and distributions of dust aerosols simulated with the GOCART model, J. Geophys. Res., 106(D17), 20,25520,274 .

Goudie, A., S. Stokes, J. Cook, S. Samieh, and O. El-Rashidi (1999), Yardang landforms from Kharga Oasis, south-western Egypt, Z. Geomorphol. Suppl., 116, 97-112.
Gourgaud, A., and P. Vincent (2004), Petrology of two continental alkaline intraplate series at Emi Koussi Volcano, Tibesti, Chad, J. Volcanol. Geotherm. Res., 129(4), 261-290.

Grell, G., J. Dudhia, and D. Stauffer (1994), A description of the fifthgeneration Penn State-NCAR mesoscale model (MM5), NCAR Technical Note NCAR/TN-398+STR, 118 pp., Natl. Cent. for Atmos. Res., Boulder, Colo.

Grove, A. (1960), Geomorphology of the Tibesti region with special reference to the western Tibesti, Geogr. J., 126(1), 18-31.

Kohfeld, K., and S. Harrison (2001), DIRTMAP, The geological record of dust, Earth Sci. Rev., 54, 81-114.

Mahowald, N. M., and L. M. Kiehl (2003), Mineral aerosol and cloud interactions, Geophys. Res. Lett., 30(9), 1475, doi:10.1029/2002GL016762.

Mahowald, N. M., R. G. Bryant, J. del Corral, and L. Steinberger (2003), Ephemeral lakes and desert dust sources, Geophys. Res. Lett., $30(2)$, 1074, doi:10.1029/2002GL016041.

Mainguet, M. (1970), Un étonnant paysage: Les cannelures gréseuse du Bembéché (nord du Tchad). Essai d'explication géomorphologique, Ann. Géogr., 79(431), 58-66.

McCauley, J., M. Grolier, and C. Breed (1977), Yardangs of Peru and other desert regions, USGS Interagency Rep., Astrogeol. 81, 177 pp., U.S. Geol. Surv., Flagstaff, Ariz.

Prospero, J. M., P. Ginoux, O. Torres, S. E. Nicholson, and T. E. Gill (2002), Environmental characterization of global sources of atmospheric soil dust identified with the NIMBUS 7 Total Ozone Mapping Spectrometer (TOMS) absorbing aerosol product, Rev. Geophys., 40(1), 1002, doi:10.1029/2000RG000095.

Riser, J. (1985), Le rôle du vent au cours des derniers millénaires dans le Bassin Saharien D'Araouane (Mali), Bulletin Assoc. Géogr. Fr., 62, 311-317.

Romero, O. E., L. Dupont, U. Wyputta, S. Jahns, and G. Wefer (2003), Temporal variability of fluxes of eolian-transported freshwater diatoms, phytoliths, and pollen grains off Cape Blanc as reflection of landatmosphere-ocean interactions in northwest Africa, J. Geophys. Res., 108(C5), 3153, doi:10.1029/2000JC000375.

Servant, M., and S. Servant (1970), Las formations lacustres et les diatomees du Quaternaire Recent du fond de la cuvette Tchadienne, Rev. Geogr. Phys. Geol. Dyn., 7, 63-76.

Tegen, I., S. P. Harrison, K. Kohfeld, I. C. Prentice, M. Coe, and M. Heimann (2002), Impact of vegetation and preferential source areas on global dust aerosol: Results from a model study, J. Geophys. Res., 107(D21), 4576, doi:10.1029/2001JD000963.

Washington, R., and M. C. Todd (2005), Atmospheric controls on mineral dust emission from the Bodéle Depression, Chad: The role of the low level jet, Geophys. Res. Lett., 32, L17701, doi:10.1029/2005GL023597.

Washington, R., M. Todd, N. Middleton, and A. Goudie (2003), Dust-storm source areas determined by the total ozone monitoring spectrometer and surface observations, Ann. Assoc. Am. Geogr., 93, 297-313.

Washington, R., M. C. Todd, S. Engelstaedter, S. Mbainayel, and F. Mitchell (2006), Dust and the low-level circulation over the Bodélé Depression, Chad: Observations from BoDEx 2005, J. Geophys. Res., 111, D03201, doi:10.1029/2005JD006502.

Williams, G. (1970), Piedmont sedimentation and late Quaternary chronology in the Biskra region of the northern Sahara, Z. Geomorphol. Suppl., 10, $40-63$.

Zender, C. S., H. Bian, and D. Newman (2003), Mineral Dust Entrainment and Deposition (DEAD) model: Description and 1990s dust climatology, J. Geophys. Res., 108(D14), 4416, doi:10.1029/2002JD002775.

C. S. Bristow, School of Earth Sciences, Birkbeck College, University of London, Malet Street, London WC1E 7HX, UK.

S. Engelstaedter, A. S. Goudie, G. Lizcano, and R. Washington, Climate Research Lab, Center for the Environment, Oxford University, South Parks Road, Oxford OX1 3QY, UK. (richard.washington@ouce.ox.ac.uk)

C. Flamant, IPSL/Service d'Aéronomie, Université Pierre et Marie Curie (Boîte 102), 4 Place Jussieu, F-75252 Paris CEDEX 05, France.

P. Ginoux, National Oceanic and Atmospheric Administration, Geophysical Fluid Dynamics Laboratory, 201 Forrestal Road, Princeton, NJ 085406649, USA

I. Koren, Department of Environmental Sciences, Weizmann Institute, P.O. Box 26, Rehovot 76100, Israel.

J. M. Prospero, University of Miami, Rosenstiel School of Marine and Atmospheric Science, 4600 Rickenbacker Causeway, Miami, FL 331491098, USA.

I. Tegen, Institute for Tropospheric Research, Permoserstrasse 15, D-04318 Leipzig, Germany.

M. C. Todd and A. Warren, Department of Geography, University College London, 26 Bedford Way, London WC1H 0AP, UK.

C. S. Zender, Department of Earth System Science, University of California, Irvine, Croul Hall, Irvine, CA 92697-3100, USA. 